\title{
Four Discourses of Digital Rights : Promises and Problems of Rights-Based Politics
}

\section{Karppinen, Kari}

2020

Karppinen , K \& Puukko , O 2020 , ' Four Discourses of Digital Rights : Promises and

Problems of Rights-Based Politics ' , Journal of Information Policy , vol. 10 , pp. 304-328 . https://doi.org/10.5325/jint

http://hdl.handle.net/10138/326934

https://doi.org/10.5325/jinfopoli.10.2020.0304

cc_by_nc_nd

publishedVersion

Downloaded from Helda, University of Helsinki institutional repository.

This is an electronic reprint of the original article.

This reprint may differ from the original in pagination and typographic detail.

Please cite the original version. 


\section{Four Discourses of Digital Rights: Promises and Problems of Rights-Based Politics} Author(s): Kari Karppinen and Outi Puukko

Source: Journal of Information Policy, 2020, Vol. 10 (2020), pp. 304-328

Published by: Penn State University Press

Stable URL: https://www.jstor.org/stable/10.5325/jinfopoli.10.2020.0304

JSTOR is a not-for-profit service that helps scholars, researchers, and students discover, use, and build upon a wide range of content in a trusted digital archive. We use information technology and tools to increase productivity and facilitate new forms of scholarship. For more information about JSTOR, please contact support@jstor.org.

Your use of the JSTOR archive indicates your acceptance of the Terms \& Conditions of Use, available at https://about.jstor.org/terms

This content is licensed under a Creative Commons Attribution-NonCommercial-NoDerivatives 4.0 International License (CC BY-NC-ND 4.0). To view a copy of this license, visit 


\title{
FOUR DISCOURSES OF DIGITAL RIGHTS
}

\author{
Promises and Problems of Rights-Based Politics
}

Kari Karppinen and Outi Puukko

\begin{abstract}
The notion of digital rights has recently generated a number of political declarations and civil society initiatives across the world. By critically examining these declarations and academic debates on digital rights, this article asks: Why is it that information policy issues are increasingly framed in terms of individual rights? And on what understandings of rights do various political, corporate, and civil society declarations of digital rights rest? The article identifies four discourses of digital rights, linked to different ideological assumptions and political contexts. Finally, possible limitations and pathologies of the rights discourse are discussed.

Keywords: digital rights, human rights, discursive contestation, Internet policy, data justice

Communication rights have often been viewed as academic or activist ideals that have failed to gain much traction in the real world of communication and information policy-making. However, rights-based perspectives have recently been brought into the mainstream by a surprisingly diverse range of political actors under the label of Internet or digital rights. As in many other fields, such as environmental and development policies, the framework of human rights now seems to constitute an umbrella, or "the international moral currency," under which all kinds of justice claims are articulated in communication and information policy. ${ }^{\mathrm{I}}$
\end{abstract}

I. See, e.g., Burdon; Ignatieff et al.; Karppinen.

Kari Karppinen: University of Helsinki

Outi Puukko: University of Helsinki

DOI: I0.5325/jinfopoli.I0.2020.0304 
Recent multistakeholder initiatives, such as "the Contract for the Web" initiated by Tim Berners-Lee, ${ }^{2}$ seem to suggest that the language of human rights provides a common ground for discourse networks comprised of state, corporate, and civil society actors who aim to shape digital policy agendas. Furthermore, the calls for the protection of citizens' digital rights have resulted in countless other high-profile reports, organizations, projects, and political declarations in different national, regional, and global contexts. ${ }^{3}$

Communication and digital rights have a long history as a cause for critical research and democratic activists globally. ${ }^{4}$ The authors of recent rights declarations, however, include not only civil society organizations, but also various coalitions of states, international organizations, and industry actors. Increasingly, the language of digital rights has even reached the agenda of dominant technology companies, where human rights are framed in terms of corporate governance and social responsibility.

Several scholars have so far empirically mapped and classified the various rights-based documents and their normative content in terms of policy issues, themes, and changes over time. ${ }^{6}$ This article draws and expands on these studies by raising more theoretical and principled questions about the notion of digital rights and the political contestations involved in defining and framing them.

Instead of arguing for any particular definition of communication or digital rights, this article approaches the articulation of "rights" as inherently indeterminate and subject to discursive contestation. We understand rights in a broad sense to include a discursive dimension in addition to legally binding norms. We define "discourse" as "practices that systematically form the objects of which they speak."7 Like Mark Goodale states,

2. The Contract for the Web was launched at the Internet Governance Forum (IGF) in November 2019. It was created by representatives of governments, companies, and civil society and aims to set out "commitments to guide digital policy agendas." See https://contractfortheweb.org/.

3. Hawtin; Pettrachin; Redeker, Gill, and Gasser.

4. See, Padovani and Calabrese. Nongovernmental networks and organizations that promote digital rights include, for example, Access Now, Association for Progressive Communications, Electronic Frontier Foundation, European Digital Rights (EDRi), Internet Rights and Principles Coalition, Ranking Digital Rights, and countless others. In addition, digital rights are increasingly on the agenda of human rights organizations like Amnesty International, Article 19 and Human Rights Watch.

5. Jørgensen, "Framing human rights." See also Jørgensen, Human Rights in the Age of Platforms.

6. Hawtin; Jørgensen, Framing the Net; Pettrachin; Redeker et al.; Weber.

7. Foucault, 54 . 
"the notion of human rights discourse goes well beyond language to include the full range of social knowledge regimes through which human rights emerges in social practice." ${ }^{8}$ Drawing from discursive approaches to policy research, ${ }^{9}$ we posit that discursive practices can produce and regulate subjects but also invite discursive struggles. ${ }^{10}$

From a critical perspective, current debates on digital rights often fail to acknowledge that rights are not simply rules and defences against power: rights claims often emerge from civil society, but can also be used as vehicles of power that encode and institutionalize specific normative ideals, relations of power, and structures of governance. ${ }^{\text {II }}$ Rather than discussing specific rights-related policy issues, the article reflects on the status of rights as a normative framework in the context of information policy, and their limitations and promises for critical research. While others have empirically analyzed the scope of various manifestations of digital rights and the processes leading to these documents, the aim here is to connect these discourses to the normative assumptions and structural conditions from which they emerge.

Assuming a critical approach to, but not rejecting the framework of digital rights, the article will ask: Why is it that media and information policy issues are increasingly framed in terms of individual rights? On what assumptions, and understanding of rights do various political, corporate, and civil society declarations of digital rights rest? And what are the possible limitations and pathologies of the rights discourse?

To examine the different understandings of digital rights, the article builds on recent academic work on digital rights, and draws examples from recent reports, declarations, and other policy documents produced by national and international governmental as well as activist, civil society, and corporate organizations. On this basis, we delineate a critical conceptual framework of four discourses of digital rights and discuss their underlying assumptions and potential implications. The process of distinguishing them is informed by our critical interpretation of both theoretical and practical sources, but it needs to be noted that the framework itself is not a result of systematic empirical analysis or any kind of representative sampling of policy documents or other empirical material. Instead, the framework aims to provide a conceptual and analytical basis for evaluating

\footnotetext{
8. Goodale, 8.

9. Fischer.

Io. e.g., Bacchi; Lombardo, Meier, and Verloo.

II. e.g., Brown; Golder; Hoover.
} 
different discursive articulations of digital rights produced by academic and political commentators. Finally, the article will point out issues that may be left out or de-emphasized by the rights discourse and suggest some perspectives that may strengthen the framework of digital rights as an analytical and normative perspective.

\section{What Rights, Against Whom, and for What Purpose?}

There is no question that the political and regulatory choices related to digital technologies raise a variety of human rights concerns, ranging from freedom of expression to access, privacy, and a range of other political and ethical questions. However, the language of rights is not the only possible strategy or normative framework for approaching the principles that should guide the future development and governance of the Internet and digital media. Political debates on these issues could conceivably rely on other normative frameworks, such as the public interest, social justice, democracy, or welfare. Then why is it that communication and information policy issues are now so often framed in terms of individual rights?

The increase in debates and declarations alone is hardly the evidence to conclude that human rights are realized in practice or that current communication and information policies would actually be guided by human rights considerations any more than before. Instead, the prominence of rights may reflect the perception that our existing fundamental human rights are increasingly threatened in the digital era, as continuing concerns over new architectures of control, the power of dominant platforms, and revelations of widespread online surveillance practices imply.

Public attention and pressing political issues also have an impact on the context in which initiatives and discourses of rights arise. The Snowden disclosures, the Cambridge Analytica scandal, and other subsequent scandals around digital platforms have all undoubtedly shaped the specific ways of discussing issues like privacy and data rights. ${ }^{{ }^{2}}$ In addition to these headlines, several civil society organizations have focused their work on documenting and campaigning against rights violations by corporate and state actors. For example, KeepItOn campaign coordinated by civil society group Access Now has tracked a global increase in the number of Internet shutdowns in recent years. ${ }^{13}$

I2. Pettrachin; Redeker et al., 3II-I2.

13. See https://www.accessnow.org/keepiton/. 
On the other hand, the emergence of digital rights discourses may also be explained by more instrumental and opportunistic factors. As a widely recognized and accepted normative framework, human rights offer an appealing framework for a variety of actors, ranging from democratic and social justice activists to states and global corporations. The language of rights possesses symbolic capital and credibility that makes it seem almost nonpolitical: rights convey an impression of absolute moral principles, which transcend different ideologies and political projects. ${ }^{14}$ As a political watchword, digital rights thus offer an appealing, and often effective language for making a variety of claims and policy demands that resonate across different political contexts. Legal scholar Julie Cohen notes that in the political economy of informational capitalism and neoliberal governmentality, the rights language can also be co-opted. ${ }^{15}$

As many critical human rights scholars have noted, the term "right" is itself indeterminate, so its uses and effects depend on who gets to fill it with meaning. ${ }^{16}$ We can thus understand current digital rights debates as part of political efforts to negotiate and contest the values and emerging principles for the governance of digital communication environment.

While there is nothing wrong with this indeterminacy in itself, this means that the discourse of digital rights is unavoidably also political, and calls for asking by whom, for what purpose, and with what consequences digital rights are invoked. A critical reading of the rights discourse thus entails that rights are not only a neutral tool for the protection of individuals, but also have a more ambivalent function as a form of power, which not only open up possibilities but also circumscribe and channel themby regulating subjects, constituting identities, distributing capabilities, influencing behavior, and creating structures of governance..$^{17}$ The digital rights discourse is thus here understood as one modality of politics, a way of presenting political demands, and as such necessarily reflects political ideologies and different normative visions of communication and society.

Either as a legal approach or as a moral discursive strategy, the rightsbased approach is typically presented in a general sense as a counterforce that protects individuals against excesses or illegitimate forms of power, including both state and corporate domination. ${ }^{18}$ The concept of digital rights itself,

\footnotetext{
I4. Moyn.

I5. Cohen.

I6. e.g., Hoover.

I7. See e.g., Golder; Hoover.

I8. e.g., Horten.
} 
however, remains vague and malleable. Digital rights can be debated from diverse perspectives and there is no shortage of disagreements about the meaning and interpretation of relevant rights, to whom they belong (users, citizens, or all humans?), the means by which they can be realized, and how they should be balanced with other concerns, such as security, economic efficiency, or other collective public interest objectives. Nor is there consensus on what kinds of institutions are needed to uphold and enforce digital rights in the nonterritorial, regulation-averse and rapidly changing digital media environment. Rights can refer to existing formal, legally binding norms, but they are also used more broadly to refer to ethical ideals or "aspirational principles," against which real-world developments are assessed. ${ }^{19}$

Besides disputes about the nature and justification of rights in general, the prefix digital can also be understood in several ways. The debates on digital rights often fail to build on, or even acknowledge, earlier debates on communication rights within communication studies and activism. ${ }^{20}$ This can create a normative disconnect where some view the debates of digital rights as a continuation of earlier struggles for communication rights, whereas others consider the context of digital rights as completely novel or significantly broader (e.g., biometric surveillance) than previous media-centric conceptions.

As Padovani, Musiani, and Pavan note, debates on rights in the digital age can be conceived as a conceptual expansion of the existing human rights discourses. ${ }^{21}$ Thus, digital rights are used variedly to refer to the implications of the digital environment for our existing rights, such as freedom of expression and privacy; the ways in which digital tools can enable the realization of other rights or social goals, such as development or welfare; or to argue for the creation of completely new human rights, such as the right to Internet access, or "the right to be forgotten." ${ }_{22}$

The fluidity of the concept allows it to be mobilized in various ways in different policy-making contexts. On the one hand, many civil society actors currently work under the motto of "digital rights are human rights," emphasizing the primacy of existing, institutionalized human rights frameworks. In comparison to state and corporate actors, civil society groups and scholars have addressed, for example, artificial intelligence

I9. Jørgensen, Framing the Net; Mathiesen.

2o. e.g., Padovani and Calabrese.

2I. Padovani, Musiani, and Pavan; 360.

22. Karppinen. 
more often on the basis of existing human rights frameworks. ${ }^{23}$ In line with this, Marianne Franklin has pointed out that codifying new rights is not a priority as long as the powerholders keep discussing whether even the full spectrum of existing human rights applies to Internet policy. ${ }^{24}$

On the other hand, the notion of digital rights has recently also been theorized from the perspectives of norm emergence and legal sociology. According to Dennis Redeker, Lex Gill, and Urs Gasser, "a constellation of initiatives that seek to articulate a set of political rights, governance norms, and limitations on the exercise of power on the Internet" constitute something that can be called digital constitutionalism. ${ }^{25}$ From this perspective, the constitutionalization of the digital environment does not refer to a fixed set of existing rules, but an ongoing process that reflects continuous technological innovations, new issues that emerge, and changing legislative outputs in this field. ${ }^{26}$ Following the idea of "societal constitutionalism," developed by Gunther Teubner, rights-based initiatives that arise from civil society can be seen as an initial phase of constitutionalization that precedes and may in a later phase become institutionalized in actual legal or constitutional norms. ${ }^{27}$ Yet the effectiveness of the process of digital constitutionalism, and whether the character of declarations changes over time from aspirational principles to legal norms, has remained debatable, partly due to varying degrees of mobilization and institutionalization. ${ }^{28}$

Scholars of digital constitutionalism have so far investigated whether there is a common understanding of core rights and principles in the emerging body of initiatives that seek to articulate a set of rights for the Internet. While some of these initiatives focus on mobilizing civil society at the regional level, most of the documents are positioned as part of the process of institutionalizing digital rights at a global level. ${ }^{29}$ In their empirical mappings, both Redeker et al. and Pettrachin found a shared nucleus of

23. For an overview of emerging AI principles, see Fjeld et al. For example, the Toronto Declaration addresses equality and non-discrimination in machine learning in relation to human rights law and standards. The document has been created by Access Now, Amnesty International and a group of experts from NGOs and academia. Moreover, Internet Rights and Principles Coalition hosted a session with Amnesty in IGF 2019, to discuss emerging AI issues in the context of existing human rights frameworks.

24. Franklin, I3.

25. Redeker et al. 303 .

26. Pettrachin.

27. Redeker et al. 304 .

28. Redeker, "Towards a European Constitution for the Internet?"; Redeker, "The Contract for the Web."

29. Pettrachin, 349 . 
rights, formulated around the principles of freedom of expression, privacy, and access to the Internet, which are addressed in the majority of the documents. Pettrachin notes, however, that this agreement tends to disappear when the focus shifts from general principles to the more specific issues, through which these general principles are articulated and where different actors emphasize different aspects of these rights..$^{30}$

Departing from traditional legal approaches to rights, the perspective of digital constitutionalism emphasizes how norms can emerge from transnational communicative exchanges, and the need to study the role of language, frames, and discourses as part of this process. ${ }^{31}$ However, what also needs to be noted is that such communicative exchanges do not necessarily constitute a level playing field where relevant norms are developed and justified in a discursively rational process. Instead, analyses of emerging digital rights and principles need to recognize the political nature of these processes and the contested framings in the manifestations of digital constitutionalism on the transnational level. This means that competing rights discourses also need to be connected to the analysis of the ideological assumptions and conditions under which they emerge, and to the contexts where they are mobilized by actors for different political purposes.

\section{Four Discourses of Digital Rights}

In philosophical and political discussions, rights have been variably understood as individual liberties, permissions, or entitlements that place obligations on others, create capabilities, or function as mere aspirational ideals. Rights can function as legal, social, or ethical principles, depending on the normative context in which they are invoked.

Without going into the philosophical debates about the nature of rights, their origin, or justification, we can analytically start deconstructing the discourse of digital rights on the basis of (I) the subject of rights (e.g., citizen, human, corporation), (2) the actions or objectives that the right entails (e.g., expression, voice, privacy, welfare), (3) the limits or constraints against whom rights are invoked (e.g., state regulation, corporate domination, other users), and (4) the framework or governance structure that justifies and enforces the right (e.g., international treaties/government, legal system, social convention, ethics).

30. Ibid., 350.

3I. Ibid., 339. 
Based on these distinctions, we outline here four different discourses of digital rights (see Table I). As an analytical framework, these discourses are here presented as conceptual abstractions, and we do not claim that positions of particular political actors would precisely mirror any of these. However, we illustrate each discourse with examples from current policy, civil society, and academic debates in order to show some instances of how they may currently find expression in practice. The choice of examples is informed by our prior knowledge and research in the field, which introduces a subjective element to the analysis. The framework is thus not a value-free or comprehensive mapping of discourses, and it does not exhaust either the possible theoretical perspectives on rights or the uses that can be empirically observed. As a starting point for further research, the elements are thus open to both conceptual and empirical challenge and questioning.

TABLE I The Framework of Four Discourses and Their Respective Conceptions of the Subject, Objectives, Constraints, and Governance Frameworks of Digital Rights

\begin{tabular}{|l|l|l|l|l|}
\hline & \multicolumn{1}{|c|}{$\begin{array}{c}\text { Subject of } \\
\text { Rights }\end{array}$} & \multicolumn{1}{|c|}{ Objectives } & \multicolumn{1}{|c|}{ Constraints } & \multicolumn{1}{|c|}{$\begin{array}{l}\text { Governance } \\
\text { Framework }\end{array}$} \\
\hline $\begin{array}{l}\text { Digital rights } \\
\text { as protection } \\
\text { of negative } \\
\text { liberties }\end{array}$ & $\begin{array}{l}\text { Private } \\
\text { individuals } \\
\text { (corporations) }\end{array}$ & $\begin{array}{l}\text { Freedom of } \\
\text { expression, } \\
\text { individual } \\
\text { choice }\end{array}$ & $\begin{array}{l}\text { State } \\
\text { intervention, } \\
\text { centralized } \\
\text { control, } \\
\text { censorship }\end{array}$ & $\begin{array}{l}\text { Fundamental } \\
\text { personal and } \\
\text { property rights; } \\
\text { limits on state } \\
\text { power }\end{array}$ \\
\hline $\begin{array}{l}\text { Positive rights } \\
\text { and state } \\
\text { obligation }\end{array}$ & $\begin{array}{l}\text { Individuals as } \\
\text { citizens, citizens } \\
\text { collectively }\end{array}$ & $\begin{array}{l}\text { Active } \\
\text { citizenship, } \\
\text { equal access, } \\
\text { effective } \\
\text { capability to } \\
\text { communicate }\end{array}$ & $\begin{array}{l}\text { Social } \\
\text { inequalities, } \\
\text { market power }\end{array}$ & $\begin{array}{l}\text { Regulation, } \\
\text { public policy }\end{array}$ \\
\hline $\begin{array}{l}\text { Rights as a } \\
\text { vehicle of } \\
\text { "informational } \\
\text { justice" }\end{array}$ & $\begin{array}{l}\text { Individuals, } \\
\text { social } \\
\text { groups, and } \\
\text { communities }\end{array}$ & $\begin{array}{l}\text { Distributive } \\
\text { justice, } \\
\text { protection } \\
\text { of vulnerable } \\
\text { groups }\end{array}$ & $\begin{array}{l}\text { Discrimination, } \\
\text { structural } \\
\text { inequalities, } \\
\text { state and } \\
\text { corporate } \\
\text { concentration } \\
\text { of power }\end{array}$ & $\begin{array}{l}\text { Regulation, } \\
\text { public policy, } \\
\text { social practices, } \\
\text { and norms }\end{array}$ \\
\hline $\begin{array}{l}\text { Affordances } \\
\text { provided by } \\
\text { platforms }\end{array}$ & $\begin{array}{l}\text { Users of specific } \\
\text { services }\end{array}$ & $\begin{array}{l}\text { Technological } \\
\text { opportunities }\end{array}$ & $\begin{array}{l}\text { State regulation; } \\
\text { arbitrary, } \\
\text { nontransparent } \\
\text { corporate } \\
\text { policies }\end{array}$ & $\begin{array}{l}\text { Self-regulation, } \\
\text { corporate social } \\
\text { responsibility, } \\
\text { terms of use }\end{array}$ \\
\hline
\end{tabular}




\section{Digital Rights as Protections of Negative Liberties}

A negative rights perspective has historically dominated the debates on free expression and human rights in the new digital environment. Both academic and early activist debates largely focused on opposing national governments' attempts to impose laws and restrictions on free speech and privacy on the Internet, rather than focusing on the broader international human rights agenda and issues such as development, gender equality, nondiscrimination, or the right to take part in cultural life. ${ }^{32}$ As Ithiel de Sola Pool argued in the early academic debates on new communication technologies, the question was "whether the electronic resources for communications can be as free of public regulation in the future as the platform and printing press have been in the past," or "whether that great achievement will become lost in the confusion about new technologies." ${ }_{33}$ A decade later, A Declaration of the Independence of Cyberspace by John Perry Barlow reflected the same ideas even more dramatically: "Governments of the Industrial World, you weary giants of flesh and steel . . on behalf of the future, I ask you of the past to leave us alone." ${ }^{34}$

Of course, the governments and corporations of the industrial world never did "leave the internet alone" and it has since become clear that digital media are intimately entangled in economic power relations and governmental and regulatory structures, and not somehow naturally beyond terrestrial politics and its methods of enforcement. On the contrary, nation-states' interests and stakes in digitalization have grown, which is reflected, for example, in the growing popularity of discourses of digital sovereignty. ${ }^{35}$ Yet, the early libertarian utopia that conceives new digital technologies as independent of the terrestrial political, economic, and legal systems is still reflected in much of the digital rights activism and discourse. ${ }^{36}$

Many of the digital-rights groups, including established advocacy groups like the Electronic Frontier Foundation or corporate sponsored initiatives like the Global Network Initiative, still reflect the ideals of the

32. Drake and Jørgensen, 5-6.

33. de Sola Pool, Io.

34. Barlow.

35. In December 2019, Russia announced tests to disconnect the country's Internet from the global network based on "sovereign internet" law. In the opening words of IGF 2019, Chancellor Angela Merkel highlighted that "digital sovereignty" doesn't mean protectionism or control of speech, but the ability to determine digital development as individuals and as a society.

36. Kreiss. 
early cyberliberties movements, which largely mobilized against rights violations by governments around the world. Similar framing also dominates the storytelling around human rights within dominant Internet companies. ${ }^{37}$ Focused on a negative conception of individual liberty, and articulated against the paternalistic or authoritarian nation-state regulation, this discourse is prominent around a range of issues, from privacy and state surveillance to traditional free expression anti-censorship activism.

An interesting variant, or perhaps a perversion of the libertarian discourse, can be found in the emerging corporate libertarian or neoliberal rights discourse, which also builds on a negative conception of rights as protections against the state-but only the subject is increasingly corporations like publishers or digital intermediaries themselves who draw on the rights discourse to resist regulation. ${ }^{38}$ Julie Cohen identifies "entrepreneurial appropriation of discourses about fundamental human rights to describe the rights and privileges of corporate entities." ${ }^{39}$ As Morgan Weiland notes, this discourse has allowed entities like Internet service providers or social media platforms to argue against any kind of regulation, such as net neutrality rules, on the basis of their free speech rights in the transmission of data or algorithmic outputs. ${ }^{40}$

To summarize this discourse in terms of our analytical framework, the negative rights discourse articulates digital rights above all as the protection of individuals' or sometimes corporations' liberty to pursue their natural self-interest, against state intervention and regulation, guaranteed by legal and constitutional limits on state power.

\section{Positive Rights and State Obligations}

Although the negative rights perspective remains influential, there are a host of organizations and movements that have adopted a more positive conception of rights. From a positive rights perspective, regulation is not seen only as an obstacle to the realization of individual rights. Instead, the realization of human rights is seen as creating obligations for policymakers (national or supranational) to promote goals, such as equal access to the Internet.

37. Jørgensen, "Framing human rights."

38. Pickard; Weiland; Cohen.

39. Cohen, 257.

40. Weiland. 
In terms of freedom of expression, for example, the positive rights approach emphasizes the structural preconditions for citizens' equal and effective use of public speech. The second and third generation human rights, such as the right to development or the right to participation in cultural life, relate even more clearly to equal conditions and opportunities to take advantage of digital tools..$^{4 \mathrm{I}}$ Instead of nonintervention, these debates also raise more explicitly the questions of the regulatory and institutional arrangements needed to actually protect and fulfil these rights. ${ }^{42}$

In the positive rights discourse, digital media is increasingly also seen as an infrastructure for the realization and promotion of human rights more generally. As a 2oII United Nations Human Rights Council report notes, because of "the transformative nature of the digital technologies" the access to these technologies and the ability to utilize them effectively should be seen as "an indispensable tool for realizing a range of human rights." 43 The perspective of digital technologies' facilitative role has also raised the question of whether access to the Internet or other digital tools, should be seen as a human right in itself, which would create a positive obligation for states to ensure connectivity. ${ }^{44}$ As Mathiesen argues, Internet access can be seen as a "derived human right" that stems from more primary human rights, whose realization increasingly depends on access to the use of digital technologies. ${ }^{45}$

Several progressive civil society movements have used a similar framing, explicitly drawing on the idea of positive communication rights as a normative framework. ${ }^{46}$ For example, the KeepItOn campaign coalition, which involves over 200 organizations, has fought against Internet shutdowns imposed by governments with the slogan: "The internet enables all our human rights, and we need our leaders to pledge to \#KeepitOn." ${ }^{47}$ Predating many of the current rights movements, the Communication Rights in the Information Society (CRIS) Campaign, which mobilized a range of civil society organizations around the World Summit on the Information Society (WSIS) process in the early 200os, explicitly defended a broader conception of rights, which included not only negative freedoms

\author{
4I. Jørgensen, Framing the Net. \\ 42. Mathiesen. \\ 43. UNHRC. \\ 44. De Hert and Kloza. \\ 45. Mathiesen. \\ 46. Padovani and Calabrese. \\ 47. KeepitOn coalition is coordinated by Access Now https://www.accessnow.org/keepiton/.
}


but also positive rights of individuals to access and effectively deploy information and knowledge to promote democratic participation and the diversity of cultures and identities online. ${ }^{48}$ Within this discourse, digital rights have also come to include demands for collective and group rights, such as language rights of minorities. The positive rights discourse has also been actively promoted by state actors, for example, in 2019, Swedish International Development Cooperation Agency (SIDA) raised concerns of shrinking democratic space online: "This is a serious concern as a free, open, and secure Internet is a driver of sustainable development and poverty reduction." 49

Reflecting the continued relevance of state actors as a site of power and influence, it has been suggested that media and information policy debates, including digital rights discourses, have witnessed "the return of the state" or a "retreat from peak globalisation." can of course involve interventions that either curtain or promote citizens' rights. While countries like Russia and China have mobilized the discourse of digital sovereignty largely to control information flows, a number of other countries have strived to pioneer more progressive Internet policies based on a set of explicit rights. Departing from the libertarian emphases of the early cyberliberties discourses, governments across the ideological spectrum have begun to codify the conceptions of digital rights that involve not only aspirations but also state obligations into binding national legislation. ${ }^{\text {sI }}$ At the regional level, the positive conception of rights is also visible in a number of European initiatives, such as the Charter of Fundamental Digital Rights of the European Union, which aims to build on and expand existing fundamental rights commitments of the European Union with more explicit rights related to personal data and automated decision-making. ${ }^{22}$

In summary, the positive rights discourse features a more political conception of citizens as the subject, with equal access and participation as the objectives of rights. The constraints against which rights are invoked here include not only state power but also markets and social inequalities more broadly. In terms of the governance framework that enforces digital

48. Alegre and Ó Siochrú; Mueller, Mathiason and Klein.

49. See https://www.sida.se/English/press/current-topics-archive/2019/stockholm-internetforum-2019/.

50. Flew, "Post-Globalisation."

5I. Redeker et al., 315 .

52. See https://digitalcharta.eu/wp-content/uploads/DigitalCharter-English-20r9-Final.pdf. 
rights, the focus here is on public policy and regulation either nationally or supranationally.

\section{Rights as a Vehicle of "Informational Justice"}

Third, related to the positive rights perspective, and its focus on equal access and individuals' effective capabilities, we can distinguish a discourse, in which rights are conceived even more broadly as a vehicle of informational justice. Here, concerns with rights don't end with individual capabilities or entitlements, but also concern broader issues like the concentration of power in the hands of few, and means to protect vulnerable groups online. Emphasizing the importance of equal access and the fair distribution of information resources, digital rights are thus framed in a broader distributive justice perspective..$^{53}$

Besides their obvious impact on freedom of expression, and other individual capabilities, this perspective sees digital media more broadly as tools that enable the promotion of broader human rights-related goals, such as economic development, political participation, combating inequality, and societal progress in general. In contrast to the positive rights perspective, and its utilitarian focus, this framework of rights is invoked not only to defend individual liberties, or even state-provided entitlements, but as a vehicle to contest and alter existing mechanisms and relations of power.

The perspective of informational justice thus presents a more complex discourse of digital rights as a counterbalance to inequalities and forms of control and domination in the digital environment. Instead of a dichotomy between individual rights and government control, human rightsbased policies are increasingly seen as an alternative to industrial control and a more closed, market-led, ecosystems. In both academic and activist uses, such nonstate threats to digital rights include the commodification of communication, the creation of new oligopolies, and other forces that may create or exacerbate social and cultural inequalities. Especially feminist and decolonial scholars and activists have highlighted marginalized groups' rights to create, use, and enjoy digital spaces and addressed a number of issues in relation to structural inequalities. ${ }^{54}$ As Ketteman and Mosene put it, "Digital rights are human rights, women's rights and LGBTQI+ rights."ss

53. Duff; Schejter and Tirosh.

54. See Mosene and Ketteman.

55. Ketteman and Mosene, 8. 
Elements of what we call the informational justice discourse can also be found in the work of various groups and nongovernment organizations (NGOs), which focus on democratic activism, development, social justice, and more democratic regulation of Internet, such as the Internet Social Forum and the Just Net Coalition. The Association for Progressive Communications (APC) has a history of contesting power structures and demanding broader inclusivity in Internet policy arenas, including, for example, a call for "a feminist internet" based on principles developed by a network of feminist digital rights activists in $2014 .{ }^{56}$ Moreover, a recent initiative launched by Just Net Coalition, Digital Justice Manifesto, calls "to own our digital future" claiming "individual as well as collective rights over data ownership" and "taking control over the techno-structures within which data operate." The manifesto aims to mobilize a wide range of movements, including those typically not present in Internet policy arenas. $^{57}$

Similar framings can be found in academic discussion outside of the Internet governance domain, in particular focusing on the political economy of data and its societal implications. ${ }^{58}$ Couldry and Meijas, for example, argue that to address the injustices embedded in what they call the system of "data colonialism," "it is time for a more radical grounding of established regulatory discourse that enables it to challenge datafication's social order." 99 Moreover, scholars working with data justice have called for fairness in the way people are made visible, represented, and treated through the production of data, ${ }^{60}$ as well as challenged the discriminatory processes and outcomes of data collection which "reflects the interconnected nature of injustice today." ${ }^{61}$

A somewhat related framing that emphasizes concerns for policymaking procedures and participation can also be found in the demands of political parties, such as Greens and Pirate Parties, at the domestic level in many national contexts. ${ }^{62}$ Combining individual freedom with more collective ideals of participatory cultural production and the notion of commons, these movements often defend what Patrick Burkart calls

56. APC; See also Redeker, "Towards a European Constitution for the Internet?"

57. The Digital Justice Manifesto is a civil society effort launched by Just Net Coalition at Internet Governance Forum 2019. See https://justnetcoalition.org/digital-justice-manifesto.pdf.

58. e.g., Zuboff; Couldry and Meijas.

59. Couldry and Meijas, I2.

6o. Taylor.

6I. Gangadharan and Jędrzej, 883.

62. Redeker et al., 315. 
"cultural environmentalism," ${ }_{3}$ which aims to defend Internet culture against both corporate and state colonization. The idea of cultural environmentalism shares with the informational justice perspective the goal of not only protecting existing legal rights, but also the contestation and alteration of hegemonic structures, such as the copyright regime.

The informational justice discourse thus extends the subject of rights from individuals to vulnerable and marginalized groups. The objectives of digital rights are discussed from the perspective of distributive justice, which is to be fostered against hegemonic power structures and both state and market colonization. In addition to regulation and public policy, the discourse also emphasizes changes at the level of everyday practices and social norms as a precondition for the realization of rights.

\section{Rights and Business: Affordances Provided by Platforms}

Fourthly, we can distinguish a perspective that includes elements of both negative and positive rights, but which altogether elides the role of statesor other supranational regulators - as the framework within which rights are justified and enforced. Instead, in this discourse digital rights are seen as affordances, or entitlements provided by platforms or digital intermediaries, such as Facebook or Google. A digital affordance can be defined as a type of action or a characteristic of actions that a technology enables through its design. ${ }^{64}$ Instead of something enforced by states, either by inaction or by means of regulation, rights are seen as inscribed in technological infrastructure. In a sense, this discourse thus affords the dominant digital platforms the de facto status of regulators.

Facebook's plan to create an oversight board for content moderation on the platform, referred to as "Supreme Court" by Mark Zuckerberg, ${ }^{65}$ exemplifies the shift where corporations take more explicitly the role of governors. This "unprecedented experiment in tech corporations selfgovernance" ${ }^{66}$ has raised the concerns of corporations' self-constitutionalizing tendencies, which might risk reducing human rights to a company's "values." ${ }^{67}$ On the other hand, transparency of content takedown decisions

\footnotetext{
63. Burkart.

64. Earl and Kimport, 132.

65. See Latonero.

66. ibid.

67. See Maroni.
} 
and appeals mechanisms can also be seen as necessary steps in comparison with the prevailing model without public accountability. ${ }^{68}$

As phrases like "code is law" and "network architecture is politics" imply, it is now widely acknowledged that new algorithmic architectures of control raise human rights concerns over freedom of expression, privacy, and other potential forms of discrimination and manipulation. However, there are different ways of approaching the power of algorithms, with some focusing on governance of algorithms and others on the governance by algorithms. ${ }^{69}$ In the latter perspective, instead of calling for regulation of these platforms, they are granted the role of de facto regulator-like entities, which in the absence of effective government actions, can be compelled by users or activists to respect digital rights as a matter of social responsibility..$^{70}$ In their mapping of digital rights declarations, Redeker et al. also found several documents, such as the Bill of Rights for Users of the Social Web and the Social Network Users' Bill of Rights, where the decision-making site that manages the rights is corporate policy and the rights-holders are framed as "users" rather than citizens..$^{71}$ They also note that the initiatives directed toward private sector actors tend to be more issue-specific, seeking to address and remedy particular grievances, rather than proposing a comprehensive framework of human rights.

The focus on private business as the locus of power in managing digital rights has also been reflected in the efforts to extend the United Nations (UN) Guiding Principles on Business and Human Rights framework, "Ruggie principles," to Internet companies. ${ }^{72}$ Three pillars of the framework assert that states' duty to protect against human rights abuses expands to businesses, companies should avoid infringing on the rights and address adverse impacts, and victims should have access to remedy. ${ }^{73}$ Based on these principles, for instance, the Ranking Digital Rights (RDR) Index ${ }^{74}$ aims to rank the world's most powerful Information and Communications Technology (ICT) companies on their disclosed commitment and policies that affect users' freedom of expression and privacy. The primary aim of

68. York and Zuckermann.

69. Musiani; Saurwein, Just and Latzer.

70. McKinnon.

7I. Redeker et al., 3I4.

72. Callamard.

73. ibid.

74. See https://rankingdigitalrights.org/; one of the authors has participated in the RDR Index as a contributing researcher. 
the index is not to influence regulation or enforce legal rights, but to help companies improve their policies and disclosures.

On one hand, attention paid to corporate policies can help bring to light the ways in which corporations exert structural power that increasingly shapes the communicative opportunities available to citizens. On the other hand, scholars have seen it urgent to make sure that human rights are treated not only as a matter of corporate social responsibility, but that formal human rights obligations are also extended to corporations. As Cohen states, institutions for recognizing and enforcing fundamental rights should work to counterbalance private economic power rather than reinforcing it. ${ }^{75}$

In summary, the affordances discourse presents users of particular services as the subject of rights. Within these services, users should exercise control over their communicative actions and opportunities. The constraint against which these rights are claimed include nontransparent corporate policies and, by implication, also state intervention, which can be avoided by situating the framework of governance at the level of selfregulation and corporate responsibility.

\section{Other Uses}

The typology presented earlier is obviously only indicative and incomplete. There are many different interpretations, permutations of the digital rights discourse, each reflecting their context of use and the interest and values of the actors that raise them.

In addition to these discourses, countless groups and movements with less organizational unity and more free-form activities and causes, such as Wikileaks, Anonymous, and even individual hacktivists, have emerged to defend "rights" against various forms of restrictions in the digital world. Many of these have been seen as disruptive forces, which bring attention to a range of injustices and political issues, without necessarily following any specific political program or manifesto. While all of these groups claim to promote digital rights, there is also criticism of their activities. Tom Sorell, for example, criticizes the means and forms of Wikileaks and Anonymous for lack of transparency, arbitrary selection of causes, and lack of concern for the rights of their "targets," which can make their activities even "subversive of central tenets of human rights." ${ }^{6}$

75. Cohen, 267.

76. Sorell, 7 . 


\section{What Is Left Out? Pathologies of Digital Rights}

Although digital rights discourse in its many forms has undoubtedly helped to increase the prominence of Internet policy issues on the policy agenda, it is not immune to the criticisms identified by several critical human rights scholars. Contemporary human rights frameworks and discourses have been criticized by radical scholars for a variety of reasons: for fostering false ideological universalism, being vague and unenforceable, or more symbolic than substantive, promoting "primordial individualism," and more. ${ }^{77}$ According to many critics, the transformations that the rights talk promise can be hollow and even pernicious, because they fail to address the root causes of injustice, and thus fail to offer any room for radical political alternatives to global capitalist liberalism. This is a criticism that has occasionally been acknowledged also within the digital rights movements, especially in discourses espousing more radical ideas of digital or data justice.

Samuel Moyn argues in his critical history of human rights that human rights discourse represents "a last utopia," in "the end of history" political juncture. ${ }^{78}$ According to Moyn, human rights have historically been used as a tool for repressing radical politics and rights discourse has acted as a colonizing space that subsumes other discourses and modes of action, such as anti-capitalism or anti-colonialism. Much of this criticism could also be seen to apply to digital rights discourses. If "the most we can hope for"79 is mitigating the power of dominant corporations with individual rights protections, then does that undermine more radical initiatives that aim to challenge the power structures of current informational capitalism? Furthermore, Franklin states that in the context of Internet governance, universalism and liberal individualism have often led to emphasizing only selected, not all, human rights. ${ }^{80}$

Recently, many scholars have problematized digital rights discourses from the perspective of economic power. Cohen, for example, criticizes the "claims about the nature of fundamental rights to internet access and use" for embedding technological essentialism in which capabilities for censorship and surveillance are "hostile add-ons" and avoidable by

77. e.g., Brown; Žižek.

78. Moyn.

79. Brown.

8o. Franklin, 22-23. 
market logic. ${ }^{81}$ Moreover, Jørgensen and Marzouki state that corporate framings of human rights may lead to a broader shift from seeing human rights as "power-regulator" toward "corporate social responsibility," which may threaten effective protection of all human rights. ${ }^{{ }^{2}}$

There is no question that the discourse of digital rights can and has been deployed as a strategic and useful instrument in struggles for a more democratic and egalitarian digital politics. However, there is also a need to interrogate the aspects that digital rights discourses do not recognize. As a traditionally individualistic concept, the rights discourse tends to de-emphasize other, more collective objectives associated with the public interest, such as social justice, development, cultural diversity, and so forth. The perspectives of digital and data justice discussed earlier, for example, provide a useful complement to the discussion on rights here, as they question to what extent individual rights can provide meaningful solutions in an environment characterized by deep societal inequalities produced by surveillance capitalism or data colonialism. In this sense, the emphasis on justice can be seen either as a competing, but no less contested, approach to the rights framework or as a way of reframing the rights discourse toward a less individualist direction. Finally, the rights discourse is obviously anthropocentric and usually fails to take into account, for instance, the enormous environmental footprint of the new digital technologies or the planetary boundaries that may place limits on the constant expansion of digital opportunities and connections. ${ }^{83}$

\section{Conclusions}

Beyond their status as existing legal obligations, digital rights can be articulated with a variety of political issues and employed by different actors for different purposes. The four discourses identified in this article highlight some of the assumptions in these different uses, including their differing conceptions of digital rights' subjects, objectives, potential constraints, and methods of enforcement. The distinctions drawn here are more analytical than strictly empirical. Although we draw from existing research and have strived to give concrete examples of these different uses, the boundaries

\footnotetext{
8I. Cohen, 4.

82. Jørgensen and Marzouki, I4.

83. e.g., Brevini and Murdock; Maxwell and Miller.
} 
of the discourses remain fluid. The focus on the actions of either states or corporations, existing human rights or emerging norms, individual rights or social justice, for example, are not mutually exclusive. Particular political actors in a given context may well draw on several, or even all of these discourses simultaneously.

This variety of conceptualizations does not mean that the language of rights should be rejected as a means of challenging existing structures of power and fighting for a more democratic information environment. The contested nature of rights is not meant to understate the merits of human rights as an established, legally defined, and internationally recognized framework that can be invoked to challenge a range of abuses by both states and corporations. Upholding human rights principles as existing legal norms also continues to be a central task for policymakers and researchers from a purely pragmatic perspective of real-world policymaking.

From a more sociological perspective, we can understand current digital rights debates as part of political efforts to negotiate and contest the values and emerging principles for the governance of the digital information environment. As the proliferation of digital rights declarations also indicates, the period of digital transformation is widely seen as calling for completely new normative frameworks and policy principles in information and communication policy. ${ }^{84}$ In line with the idea of digital constitutionalism, actors that take part in these initiatives and processes all contribute to a discursive exchange where the principles are crystallized and perhaps eventually institutionalized.

However, the language of rights is not the only possible framework for developing these principles, and as socially constructed ideals, we should not take their content as given. As Michael Ignatieff has argued, human rights must not become an idolatry that brings closure to political debate, but should be seen more as an unfinished project that constantly throws up new problems and political tensions. ${ }^{85}$ In this sense, rights-based politics is no different from alternative normative framings around welfare, social justice, or democracy.

Instead of advocating a particular definition of digital rights, or arguing that we need to replace the framework of rights with another framework or language of justifying normative claims, the main argument of this article is that there is a need to be aware of the assumptions, intentions, and

84. e.g., Brown and Marsden; Duff; Picard and Pickard; Schejter and Tirosh. 85. Ignatieff. 
effects of the different uses of digital rights. Instead of assuming that the multistakeholder processes and declarations will result in a shared understanding of universal rights and principles, we need to acknowledge the possible pathologies of the rights discourses, as well as the fact that some actors will have more resources to advance their interpretations than others. If we understand the rights discourse as a political modality or an ethos for making claims about desirable ends in information policy, the discourse of rights remains unavoidably plural and political. From this perspective, a crucial challenge for research on digital rights is not only to help facilitate an emerging global consensus but to also clarify the concrete policy and practical implications of alternative visions and claims.

\section{BIBLIOGRAPHY}

Access Now. "KeepitOn campaign." Accessed January 29, 2020. https://www.accessnow.org/ keepiton/.

Alegre, Alan, and Seán Ó Siochrú. "Communication Rights." In Word Matters: Multicultural Perspectives on Information Societies, edited by Alain Ambrosi, Valérie Peugeot, and Daniel Pimienta. Caen, France: C \& F Publishers, 2005.

Amnesty International and Access Now. "The Toronto Declaration." Accessed January 28, 2020. https://www.torontodeclaration.org/.

APC (Association for Progressive Communications). "Making a Feminist Internet." In Many Worlds, Many Nets, Many Visions: Critical Voices, Visions and Vectors for Internet Governance, edited by Katharina Mosene and Matthias Ketteman. Berlin: Hans-BredowInstitut, 2019.

Bacchi, Carol. "Discourse, Discourse Everywhere: Subject "Agency" in Feminist Discourse Methodology" Nordic Journal of Women's Studies I3, no. 3 (August 2006): 198-209.

Barlow, John P. A Declaration of the Independence of Cyberspace, 1996. Accessed June 6, 2020. http://www.eff.org/cyberspace-independence.

Brevini, Benedetta, and Graham Murdock, eds. Carbon Capitalism and Communication: Confronting Climate Crisis. New York and London: Palgrave Macmillan, 2017.

Brown, Wendy. "“The most we can hope for...": Human Rights and the Politics of Fatalism." The South Atlantic Quarterly 103, no. 2-3 (Spring-Summer 2004): 45I-63.

Brown, Ian, and Christopher T. Marsden. Regulating Code. Good Governance and Better Regulation in the Information Age. Cambridge, MA: MIT Press, 2013.

Burdon, Peter D. "Environmental Human Rights: A Constructive Critique." In The Research Handbook on Human Rights and the Environment, edited by Anna Grear and Louis J. Kotzé, 6I-78. Cheltenham, UK: Edward Elgar, 2015.

Burkart, Patrick. Pirate Politics. The Information Policy Contests. Cambridge, MA: MIT Press, 2014 .

Callamard, Agnès. "The Human Rights Obligations of Non-State Actors." In Human Rights in the Age of Platforms edited by Rikke F. Jørgensen: 19I-225, Cambridge, MA: MIT Press, 2019.

Charter of Fundamental Digital Rights of the European Union. Accessed February 3, 2020. https://digitalcharta.eu/wp-content/uploads/DigitalCharter-English-2org-Final.pdf. 
Cohen, Julie E. Between Truth and Power: The Legal Constructions of Informational Capitalism. New York: Oxford University Press, 2019.

Couldry, Nick, and Ulises Meijas. "Making Data Colonialism Liveable: How Might Data's Social Order Be Regulated?” Internet Policy Review 8, no. 2 (June 30, 2019). doi:IO.I4763/20I9.2.I4II.

De Hert, Paul and Dariusz Kloza. "Internet (access) as a new fundamental right. Inflating the current rights framework?" European Journal of Law and Technology 3, no. 3, (2OI2). Accessed June 5, 2020. http://ejlt.org/article/view/I23/268.

Drake, William J. and Rikke F. Jørgensen. "Introduction." In Human Rights in the Global Information Society, edited by Rikke F. Jørgensen. Cambridge, MA: MIT Press, 2006.

Duff, Alistair. A Normative Theory of the Information Society, New York: Routledge, 2012.

Earl, Jennifer, and Katrina Kimport. Digitally enabled social change: Activism in the Internet age. Cambridge, MA: MIT Press, $201 \mathrm{I}$.

Flew, Terry. "Post-globalisation." Javnost - The Public 25, no I-2 (2018): IO2-I09. doi:I0.IO80/13 I83222.20I8.1418958.

Fischer, Frank. Reframing Public Policy: Discursive Politics and Deliberative Practices. Oxford: Oxford University Press, 2003.

Fjeld, Jessica, Nele Achten, Hannah Hilligoss, Adam Nagy, and Madhulika Srikumar. "Principled Artificial Intelligence: Mapping Consensus in Ethical and Rights-Based Approaches to Principles for Ai." Berkman Klein Center Research Publication, No. 2020-I (January, 2020). Accessed June 5, 2020. https://ssrn.com/abstract=3518482.

Foucault, Michel. Archaeology of Knowledge. New York: Routledge, 2002.

Franklin, Marianne I. "Civil Society and the Internet Governmentality Complex: Manufacturing Global Consensus.” Accessed February 4, 2020. https://www.academia.edu/363619I4/ Civil_Society_and_the_Internet_Governmentality_Complex_Manufacturing_Global_ Consensus.

Gangadharan, Seeta Peńa, and Niklas Jędrzej. "Decentering Technology in Discourse on Discrimination." Information, Communication \& Society 22, no. 7, (May 2019): 882-99. doi:10.1080/1369118X.2019.1593484.

Golder, Ben. Foucault and the Politics of Rights. Stanford: Stanford University Press, 20I5.

Goodale, Mark. "Locating Rights, Envisioning Law Between the Global and the Local.” In The Practice of Human Rights: Tracking Law Between the Global and the Local, edited by Mark Goodale and Sally Engle Merry, I-38, Cambridge, UK: Cambridge University Press, 2007.

Hawtin, Dixie. "Internet Charters and Principles: Trends and Insights." Global Information Society Watch, 5I-54. South Africa: HIVOS and Association for Progressive Communications, 2 OII.

Hoover, Joe. Reconstructing Human Rights: A Pragmatic and Pluralist Inquiry in Global Ethics. Oxford: Oxford University Press, 2016.

Horten, Monica. The Closing of the Net. Cambridge, UK: Polity Press, 2016.

Ignatieff, Michael, K. Anthony Appiah, David A. Hollinger, Thomas W. Laqueur, and Diane F. Orentlicher. Human Rights as Politics and Idolatry, edited by Amy Gutmann. Princeton: Princeton University Press, 200I.

Jørgensen, Rikke F. "Framing Human Rights: Exploring Storytelling within Internet Companies.” Information, Communication \& Society 2I, no. 3 (February 20I7): 340-55. doi:IO.IO80/I3 69118X.2017.1289233.

- Framing the Net. Human Rights and the Internet. Cheltenham, UK: Edgar Elgar, 2013. - ed. Human Rights in the Age of Platforms. Cambridge, MA: MIT Press, 20I9.

Jørgensen, Rikke F., and Meryem Marzouki. "Internet Governance and the Reshaping of Global Human Rights Legacy at WSIS+Io.” GigaNet Annual Symposium (November 2015), João Pessoa, Brazil. 
Just Net Coalition. "Digital Justice Manifesto." Accessed 29 January, 2020. https://justnetcoalition.org/digital-justice-manifesto.pdf.

Karppinen, Kari. "Human Rights and the Digital." In Routledge Companion to Media and Human Rights, edited by Howard Tumber and Silvio Waisbord, 95-103. London: Routledge, 2017.

Ketteman, Matthias and Katharina Mosene. "Space for All, Voice for All! Towards a More Inclusive Internet Governance 2020+." In Many Worlds, Many Nets, Many Visions: Critical Voices, Visions and Vectors for Internet Governance, edited by Katharina Mosene and Matthias Ketteman, 7-9. Berlin: Hans-Bredow-Institut, 2019.

Kreiss, Daniel. "A Vision of and for the Networked World. John Perry Barlow's A Declaration of Independence of Cyberspace at Twenty." In Media Independence: Working with Freedom or Working for Free?, edited by James Bennett and Niki Strange, New York: Routledge, 2015.

Latonero, Mark. "Can Facebook's Oversight Board Win People's Trust?" Harvard Business Review (January 29, 2020). Accessed June 5, 2020. https://hbr.org/2020/oI/ can-facebooks-oversight-board-win-peoples-trust.

Lombardo, Emanuela, Petra Meier, and Mieke Verloo. "Discursive Dynamics in Gender Equality Politics: What about 'Feminist Taboos'?" European Journal of Women's Studies 17, no. 2 (May 2010): 105-23.

Maroni, Marta. "Some reflections on the announced Facebook Oversight Board." (October 17, 2019). Robert Schuman Centre for Advanced Studies, Centre for Media Pluralism and Media Freedom (CMPF). Accessed June 5, 2020. https://cmpf.eui.eu/somereflections-on-the-announced-facebook-oversight-board/.

Mathiesen, Kay. "Human Rights for the Digital Age." Journal of Mass Media Ethics 29, no. I (January 20I4): 2-I8. doi:I0.IO80/08900523.20I4.863I24.

Maxwell, Richard, and Toby Miller. Greening the Media. Oxford: Oxford University Press, 2012.

McKinnon, Rebecca. Consent of the Networked: The World-wide Struggle for Internet Freedom. New York: Basic Books, 2012.

Mosene, Katharina, and Matthias Ketteman, eds. Many Worlds, Many Nets, Many Visions: Critical Voices, Visions and Vectors for Internet Governance. Berlin: Hans-Bredow-Institut, 2019. https://www.hiig.de/wp-content/uploads/2019/II/IGF-Statements-Critical-VoicesWEB.pdf.

Moyn, Samuel. The Last Utopia: Human Rights in History. Cambridge, MA: Harvard University Press, 2012.

Mueller, Milton, John Mathiason, and Hans Klein. "The Internet and Global Governance: Principles and Norms for a New Regime." Global Governance 13, no. 2 (2007): 237-54. Accessed June 5, 2020. https://www.jstor.org/stable/27800656.

Musiani, Francesca. "Governance by Algorithms." Internet Policy Review 2, no. 3, (2013). doi:I0.14763/2013.3.188.

Padovani, Claudia, and Andrew Calabrese, eds. Communication Rights and Social Justice: Historical Accounts of Transnational Mobilizations. Basingstoke, UK: Palgrave Macmillan, 2014 .

Padovani, Claudia, Francesca Musiani, and Elena Pavan. "Investigating Evolving Discourses on Human Rights in the Digital Age: Emerging Norms and Policy Challenges." The International Communication Gazette 72, no. 4-5 (May 2010): 359-78.

Pettrachin, Andrea. "Towards a Universal Declaration on Internet Rights and Freedoms?" The International Communication Gazette 80, no. 4 (June 2018): 337-53. doi:I0.II77/1748048518757139.

Picard, Robert, and Victor Pickard. Essential Principles for Contemporary Media and Communications Policymaking. Oxford: Reuters Institute for the Study of Journalism, University of Oxford, 2017. 
Pickard, Victor. "Toward a People's Internet: The Fight for Positive Freedoms in an Age of Corporate Libertarianism." In Blurring the Lines Market-Driven and Democracy-Driven Freedom of Expression, edited by Maria Edström, Andrew T. Kenyon, and Eva-Maria Svensson: 6I-8.Göteborg, Sweden: Nordicom, 2016.

Pool, Ithiel de Sola. Technologies of Freedom. Cambridge, MA: Harvard University Press, 1983.

Ranking Digital Rights. Accessed January 29, 2020. https://rankingdigitalrights.org/.

Redeker, Dennis. "The Contract for the Web: The newest manifestation of digital constitutionalism?" Völkerrechtsblog, (29 November, 2019). doi:I0.17176/20191129-I80645-0.

. "Towards a European Constitution for the Internet? Comparative Institutionalization and Mobilization in European and Transnational Digital Constitutionalism." GigaNet Annual Symposium, (November 2019).

Redeker, Dennis, Lex Gill, and Urs Gasser. "Towards Digital Constitutionalism? Mapping Attempts to Craft an Internet Bill of Rights." The International Communication Gazette 80, no. 4 (June 2018): 302-I9. doi:I0.II77/174804851875712I.

Saurwein, Florian, Natascha Just, and Michael Latzer. "Governance of Algorithms: Options and Limitations." Info 17, no. 66, (July 2015): 35-49. doi:I0.I108/info-05-2015-0025.

Schejter, Amit, and Noam Tirosh. A Justice-Based Approach for New Media Policy: In the Paths of Righteousness. Cham, Switzerland: Palgrave Macmillan, 2016.

SIDA. "Stockholm Internet Forum 2019: Mobilizing for a Free, Open and Secure Internet." Accessed February 4, 2020. https://www.sida.se/English/press/ current-topics-archive/2019/stockholm-internet-forum-2019/.

Sorell, Tom. "Human Rights and Hacktivism. The Cases of Wikileaks and Anonymous." Journal of Human Rights Practice 7, no.3, (November 2015): 39I-4IO. doi:Io.Io93/jhuman/huvoI2.

Taylor, Linnet. "What Is Data Justice? The Case for Connecting Digital Rights and Freedoms Globally." Big Data \& Society 4, no. 2, (December 2017). doi:I0.II77/2053951717736335.

UNHRC-United Nations Human Rights Council. Report of the Special Rapporteur on the Promotion and Protection of the Right to Freedom of Opinion and Expression, Frank La Rue, 20Ir. Accessed June 5, 2020. http://www2.ohchr.org/english/bodies/hrcouncil/docs/ I7session/A.HRC.17.27_en.pdf.

Weber, Rolf H. Principles for Governing the Internet: A Comparative Analysis. Paris: UNESCO, 2015. Accessed June 5, 2020. https://unesdoc.unesco.org/ark:/48223/pfoooo234435.

Weiland, Morgan N. "Expanding the Periphery and Threatening the Core: The Ascendant Libertarian Speech Tradition." Stanford Law Review 69, no. 5 (May 2017): 1389-472.

World Wide Web Foundation. "The Contract for the Web." Accessed January 28, 2020. https:// contractfortheweb.org/.

York, Jillian C., and Ethan Zuckerman. "Moderating the Public Sphere." In Human Rights in the Age of Platforms, edited by Rikke F. Jørgensen, I37-6I, Cambridge, MA: MIT Press, 2019.

Žižek, Slavoj. "Against Human Rights." New Left Review 34, (July-August 2005): II5-3I.

Zuboff, Shoshana. The Age of Surveillance Capitalism: The Fight for a Human Future at the New Frontier of Power. New York: Public Affairs, 2019. 